\title{
MACC regional multi-model ensemble simulations of birch pollen dispersion in Europe
}

\author{
M. Sofiev ${ }^{1}$, U. Berger ${ }^{2}$, M. Prank ${ }^{1}$, J. Vira ${ }^{1}$, J. Arteta ${ }^{5}$, J. Belmonte ${ }^{3}$, K.-C. Bergmann ${ }^{4}$, F. Chéroux ${ }^{5}$, H. Elbern ${ }^{6}$, \\ E. Friese ${ }^{6}$, C. Galan ${ }^{7}$, R. Gehrig ${ }^{8}$, D. Khvorostyanov ${ }^{9}$, R. Kranenburg ${ }^{10}$, U. Kumar ${ }^{11}$, V. Marécal ${ }^{5}$, F. Meleux ${ }^{12}$, \\ L. Menut ${ }^{9}$, A.-M. Pessi ${ }^{13}$, L. Robertson ${ }^{14}$, O. Ritenberga ${ }^{15}$, V. Rodinkova ${ }^{16}$, A. Saarto $^{13}$, A. Segers ${ }^{10}$, E. Severova ${ }^{17}$, \\ I. Sauliene ${ }^{18}$, P. Siljamo ${ }^{1}$, B. M. Steensen ${ }^{19}$, E. Teinemaa ${ }^{20}$, M. Thibaudon ${ }^{21}$, and V.-H. Peuch ${ }^{22}$ \\ ${ }^{1}$ Finnish Meteorological Institute, Erik Palmenin Aukio 1, Helsinki, Finland \\ ${ }^{2}$ Medical University of Vienna, Vienna, Austria \\ ${ }^{3}$ Institut de Ciència i Tecnologia Ambientals, Universitat Autònoma de Barcelona, Barcelona, Spain \\ ${ }^{4}$ Foundation German Pollen Information Service, Berlin, Germany \\ ${ }^{5}$ Groupe d'Étude de l'Atmosphère Méréorologique/Centre National de Recherches Météorologiques, \\ CNRS-Météo-France, Toulouse, France \\ ${ }^{6}$ Rhenish Institute for Environmental Research at the University of Cologne, Cologne, Germany \\ ${ }^{7}$ University of Cordoba, Cordoba, Spain \\ ${ }^{8}$ Federal Office of Meteorology and Climatology Meteo Swiss, Zurich, Switzerland \\ ${ }^{9}$ Laboratoire de Météorologie Dynamique, CNRS, Ecole Polytechnique, Ecole Normale Supérieure, Université P.M. Curie, \\ Ecole Nationale des Ponts et Chaussées, Palaiseau, France \\ ${ }^{10}$ TNO, Utrecht, the Netherlands \\ ${ }^{11}$ Royal Netherlands Meteorological Institute, De Bilt, the Netherlands \\ ${ }^{12}$ INERIS, Institut National de l'Environnement Industriel et des Risques, Verneuil en Halatte, France \\ ${ }^{13}$ University of Turku, Turku, Finland \\ ${ }^{14}$ SMHI, Swedish Meteorological and Hydrological Institute, Norrköping, Sweden \\ ${ }^{15}$ University of Latvia, Riga, Latvia \\ ${ }^{16}$ VNMU, Vinnitsa National Medical University, Vinnitsa, Ukraine \\ ${ }^{17}$ Moscow State University, Moscow, Russia \\ ${ }^{18}$ Siauliai University, Siauliai, Lithuania \\ ${ }^{19}$ MET Norway, Oslo, Norway \\ ${ }^{20}$ Estonian Environmental Research Centre, Tallinn, Estonia \\ ${ }^{21}$ RNSA, Brussieu, France \\ ${ }^{22}$ European Centre of Medium-Range Weather Forecast, Reading, UK
}

Correspondence to: M. Sofiev (mikhail.sofiev@fmi.fi)

Received: 30 December 2014 - Published in Atmos. Chem. Phys. Discuss.: 18 March 2015

Revised: 29 June 2015 - Accepted: 2 July 2015 - Published: 23 July 2015

\begin{abstract}
This paper presents the first ensemble modelling experiment in relation to birch pollen in Europe. The sevenmodel European ensemble of MACC-ENS, tested in trial simulations over the flowering season of 2010, was run through the flowering season of 2013. The simulations have been compared with observations in 11 countries, all members of the European Aeroallergen Network, for both individ-
\end{abstract}

ual models and the ensemble mean and median. It is shown that the models successfully reproduced the timing of the very late season of 2013, generally within a couple of days from the observed start of the season. The end of the season was generally predicted later than observed, by 5 days or more, which is a known feature of the source term used in the study. Absolute pollen concentrations during the sea- 
son were somewhat underestimated in the southern part of the birch habitat. In the northern part of Europe, a recordlow pollen season was strongly overestimated by all models. The median of the multi-model ensemble demonstrated robust performance, successfully eliminating the impact of outliers, which was particularly useful since for most models this was the first experience of pollen forecasting.

\section{Introduction}

During the last 30 years, the prevalence of airborne allergy and asthma in Europe has increased 4-fold, reaching 15$40 \%$ of the population. According to the European Federation of Allergy and Airway Diseases Patients Associations, 80 million (24.4\%) adults living in Europe are allergic. The allergy prevalence in children is $30-40 \%$ and increasing (Laatikainen et al., 2011; Rönmark et al., 2009). Allergy to various types of pollen in the air, exacerbated by co-exposure to chemical pollutants and fine aerosols, is the number one chronic disease in Europe, overshadowing allergy to house dust mite and affecting over $20 \%$ of the population (Bousquet et al., 2007).

Among the allergenic plants, grass and birch pollen affect about 40 and $25 \%$ of all hay fever sufferers in Europe respectively (Heinzerling et al., 2009). Birch is a strong allergy-provoking tree with a population-wide sensitisation of approximately $15 \%$ (WHO, 2003). The distribution of silver birch (Betula pendula Roth.) and downy birch (B. pubescens L.) extends from mountains in the temperate climate of southern Europe to Fennoscandia and Siberia (Atkinson, 1992; OECD, 2003).

It has long been known that the bulk of pollen is deposited near the source plant (Raynor et al., 1970; Tampieri et al., 1977; Wright, 1953, 1952). However, birches, as well as other species (Alnus, Carpinus, Corylus, Ostrya, Fagus, Quercus, Castanea) belonging to the order Fagales, are windpollinated trees generating vast amounts of pollen to ensure a sufficient level of fertilisation of female flowers over receptor regions. Their pollen grains are sufficiently small and light to facilitate the atmospheric transport of up to $1 \%$ of the released material over thousands of kilometres when weather conditions are suitable (Sofiev et al., 2006a). This phenomenon was noticed in the middle of the twentieth century (Erdtman, 1937, 1935, 1931; Gregory, 1961). Later, it was recognised that the long-range transported pollen can have a substantial health impact (Viander and Koivikko, 1978) and facilitate a large-scale redistribution of genetic material (Lindgren et al., 1995). Long-range transport of pollen is practically unpredictable with local observations or statistical models. However, up until the last 2 decades no practical instruments had been developed for its quantitative evaluation and forecasting.

Starting from the 1990s, episodes of pollen dispersion on regional and continental scales have been addressed in nu- merous studies (Belmonte et al., 2000; Corden et al., 2002; Damialis and Gioulekas, 2005; Hjelmroos, 1992; Latalova et al., 2002; Mahura et al., 2007; Ranta and Satri, 2007; Ranta et al., 2011; Rantio-Lehtimaki, 1994; Siljamo et al., 2008c; Skjøth et al., 2008; Sofiev et al., 2012b, 2006a; YliPanula et al., 2009; see also reviews by Smith et al., 2014, and Sofiev and Bergmann, 2013). It was shown that, although the features of each specific long-range transport episode vary widely, there may be a systematic pattern in the springtime pollen redistribution in Europe with prevailing transport directions, main source and receptor regions, etc. There have been several attempts to reveal such a pattern via a multiannual analysis (Damialis and Gioulekas, 2005; Siljamo et al., 2008a, c, 2006; Skjøth et al., 2009, 2007; Smith et al., 2008; Sofiev et al., 2006a; Stach et al., 2007; Yli-Panula et al., 2009) but the picture is still largely incomplete.

The main tool for analysing the pollen distribution on regional and continental scales is numerical modelling that combines phenological models covering pollen maturation and presentation (the pollen source term) with the atmospheric dispersion model. Currently, there exist four comparatively independent formulations of the source terms for birch pollen. The European-scale source term used in the current study was developed for the SILAM model (http://silam. fmi.fi) by an international consortium within the scope of the POLLEN project of the Academy of Finland (Siljamo et al., 2012; Sofiev et al., 2012a). Various versions of the model have been used for forecasts of pollen distribution in Europe starting from 2005 (Sofiev et al., 2006a) and reanalysis of the flowering seasons back to 1997 (Siljamo et al., 2008c; Veriankaitè et al., 2010). The COSMO-ART birch module was developed at the University of Karlsruhe (Helbig et al., 2004; Vogel et al., 2008) and MeteoSwiss (Pauling et al., 2012; Zink et al., 2013) and is currently used for pollen forecasting for central and south-western Europe. Development is also going on in Denmark with the regional ENVIRO-HIRLAM system (Mahura et al., 2009) applied for forecasting over northern Europe. Finally, combining the COSMO-ART and SILAM source terms, Efstathiou et al. (2011) developed a regional-scale model for the USA and applied it to birch and ragweed.

MACC (Monitoring of Atmospheric Composition and Climate, http://www.gmes-atmosphere.eu) pollen simulations are based on the SILAM source term. Its formulations and input data have been shared among the seven regional modelling teams of MACC and, in co-operation with the European Aeroallergen Network (EAN), set into operational multi-model ensemble forecasting of birch pollen in Europe.

The goal of the current paper is to present and evaluate the results of the first ensemble modelling of birch pollen in Europe during the season of 2013.

The next section will present the models and setup of the simulations as well as the observation data used for evaluation of the model predictions. The results section will present the outcome of the simulations and the quality scores of the 
individual models and the ensemble. The discussion section will be dedicated to analysis of the results, considerations of the efficiency of the multi-model ensemble for pollen, and identification of the most pressing development needs.

\section{Materials and methods}

This section presents the regional models used in the study, outlines the birch pollen source term implemented in all of them, and introduces the pollen observations used for evaluation of the model predictions.

\subsection{Dispersion models}

The dispersion models used in the study comprise the MACC-II European ensemble, which is described in detail in Marécal et al. (2015). In the following, only the model features relevant for the pollen atmospheric transport calculations are described.

The ensemble consisted of seven models.

- CHIMERE (http://www.lmd.polytechnique.fr/chimere/) is an Eulerian regional-scale chemistry-transport model for gaseous and aerosol species (Menut et al., 2013). Pollen is implemented as a special aerosol with a prescribed species-specific size (currently birch or ragweed) between 20 and $22 \mu \mathrm{m}$ and density of 800 and $1050 \mathrm{~kg} \mathrm{~m}^{-3}$ respectively. The resulting gravitational settling velocity is $1.2-1.3 \mathrm{~cm} \mathrm{~s}^{-1}$. The transport processes affecting pollens, such as advection, turbulent mixing, and wet deposition, are implemented in the same way as for other aerosols. Dry deposition is described via gravitational settling only, which dominates for pollens (Sofiev et al., 2006a), whereas resuspension is parameterized following Helbig et al. (2004).

- EMEP model of EMEP/MSC-W (European Monitoring and Evaluation Programme/Meteorological Synthesizing Centre - West) is a chemical transport model developed at the Norwegian Meteorological Institute and described in Simpson et al. (2012). It is flexible with respect to the choice of projection and grid resolution. Dry deposition is handled in the lowest model layer. A resistance analogy formulation is used to describe dry deposition of gases, whereas for aerosols the mass-conservation equation is adopted from Venkatram (1978) with the dry deposition velocities dependent on the land use type. Wet scavenging is dependent on precipitation intensity and is treated differently within and below clouds. The below-cloud scavenging rates for particles are calculated based on Scott (1979). The rates are size dependent, growing for larger particles.

- EURAD-IM (http://www.eurad.uni-koeln.de) is an Eulerian mesoscale chemistry transport model involving advection, diffusion, chemical transformation, wet and dry deposition, and sedimentation of tropospheric trace gases and aerosols (Hass et al., 1995; Memmesheimer et al., 2004). It includes 3D-VAR and 4D-VAR chemical data assimilation (Elbern et al., 2007) and is able to run in nesting mode. The positive definite advection scheme of Bott (1989) is used to solve the advective transport and the aerosol sedimentation. An eddy diffusion approach is applied to parameterize the vertical sub-grid-scale turbulent transport (Holtslag and Nieuwstadt, 1986). Dry deposition of aerosol species is treated as size dependent using the resistance model of Petroff and Zhang (2010). Wet deposition of pollen is parameterized according to Baklanov and Sorensen (2001).

- LOTOS-EUROS (http://www.lotos-euros.nl/) is an Eulerian chemical transport model (Schaap et al., 2008). The advection scheme follows Walcek and Aleksic (1998). The dry deposition scheme of Zhang et al. (2001) is used to describe the surface uptake of aerosols. Below-cloud scavenging is described using simple scavenging coefficients for particles (Simpson et al., 2003).

- MATCH (http://www.smhi.se/en/research/researchdepartments/air-quality/match-transport-andchemistry-model-1.6831) is an Eulerian multi-scale chemical transport model with mass-conservative transport and diffusion based on a Bott-type advection scheme (Langner et al., 1998; Robertson and Langner, 1999). For birch pollen, dry deposition is mainly treated by sedimentation and a simplified wet scavenging scheme is applied. The temperature sum from March onwards, driving the birch pollen emission, is determined outside the model and fed into the emission module.

- MOCAGE (http://www.cnrm.meteo.fr/gmgec-old/site_ engl/mocage/mocage_en.html) is a multi-scale dispersion model with grid-nesting capability (Josse et al., 2004; Martet et al., 2009). The semi-Lagrangian advection scheme of Williamson and Rasch (1989) is used for the grid-scale transport. The convective transport is based on the parameterization proposed by Bechtold et al. (2001) whereas the turbulent diffusion follows the parameterization of Louis (1979). Dry deposition including the sedimentation scheme follows Seinfeld and Pandis (1998). The wet deposition by the convective and stratiform precipitations is based on Giorgi and Chameides (1986).

- SILAM (http://silam.fmi.fi) is a meso-to-global-scale dispersion model (Sofiev et al., 2008; see also the review by Kukkonen et al., 2012). The Eulerian advection-diffusion core used in this study is based on the algorithms of Galperin (2000) and Sofiev (2002). 
The dry deposition scheme (Kouznetsov and Sofiev, 2012) is applicable for a wide range of particle sizes including coarse aerosols, which are primarily removed by sedimentation. The wet deposition parameterization distinguishes between sub- and in-cloud scavenging by both rain and snow (Sofiev et al., 2006b). For coarse particles, impaction scavenging is dominant below the cloud. The model is capable of 3D- and 4D-VAR data assimilation (Vira and Sofiev, 2012), also applicable to birch.

- ENSEMBLE models were generated by the arithmetic average and median calculated from seven model fields for each hour.

\subsection{Birch pollen source term}

All models of this study are equipped with the same birch pollen source term (Sofiev et al., 2012) verified for the season of 2006 by Siljamo et al. (2012). The formulations and input data are open at http://silam.fmi.fi/MACC. The main input data set is the birch habitat map compiled by Sofiev et al. (2006a) with a spatial resolution of $0.5^{\circ} \times 0.5^{\circ}$ longitudelatitude. The birch productivity is assumed to be the same in all years and equal to $10^{9}$ pollen $\mathrm{m}^{-2}$ season $^{-1}$.

The flowering description follows the concept of thermal time phenological models and, in particular, the doublethreshold air temperature sum approach of Linkosalo et al. (2010) modified by Sofiev et al. (2012), which determines the flowering propagation during the whole spring season. Within that approach, the heat accumulation starts on a day in spring (1 March in the current setup) and continues throughout the season. Flowering starts when the accumulated heat reaches the starting threshold and continues until the heat reaches the ending threshold. The rate of heat accumulation is the main controlling parameter for pollen emission: the model establishes direct proportionality between the flowering stage and fraction of the heat sum accumulated to-date.

Apart from temperature, the pollen release rate is modulated by ambient humidity, precipitation, and wind speed. Following Sofiev et al. (2012), higher relative humidity $(\mathrm{RH})$ and rain reduce the release, completely stopping it for $\mathrm{RH}>80 \%$ and/or rain $>0.1 \mathrm{~mm} \mathrm{~h}^{-1}$. Strong wind promotes it by up to $50 \%$. Atmospheric turbulence is taken into account via the turbulent velocity scale and thus becomes important only in cases close to free convection. In stable or neutral stratification and calm conditions the release is suppressed by $50 \%$.

Local-scale variability of the flowering results in the need to include probabilistic description of the flowering propagation (Siljamo et al., 2008b). In the simplest form, the probability of an individual tree entering the flowering stage can be considered via the uncertainty of the temperature sum threshold determining the start of flowering for the grid cell.
The end of the season is described via the open-pocket principle: the flowering continues until the initially available amount of pollen is completely released.

\subsection{Pollen observations}

The observations for the model evaluation in 2013 have been provided by the following 11 members of the EAN: Austria, Estonia, Germany, Finland, France, Latvia, Lithuania, Russia, Spain, Switzerland, and Ukraine. Additionally, the data for the initial model testing for the season of 2010 were provided by Austria, Finland, Germany, Latvia, Lithuania, Russia, Spain, Switzerland, and Ukraine. In total, information from 165 sites in 2010 and 186 sites in 2013 was made available to the modelling teams. Among these, 21 stations in mountain valleys of the Alps and Pyrenees were flagged as not representative on the regional scale and excluded from the analysis (see the Discussion section). The analysis below concentrates on the season of 2013 as the data for 2010 were mainly used for setting up and verifying the pollen source term implementations. However, a comparison of these years is used to illustrate the variability of pollen seasons and the ability of the models to reproduce it.

Pollen monitoring was performed with Burkard 7-day and Lanzoni 2000 pollen traps based on the Hirst design (Hirst, 1954). The pollen grains were collected at an airflow rate of $10 \mathrm{~L} \mathrm{~min}^{-1}$. The observations covered the period from March until September, with some variations between the countries. Daily observations were used. Following the EAN recommendations (Galán et al., 2014; Jäger et al., 1995), most samplers were located at heights of between 10 and $30 \mathrm{~m}$ on the roofs of suitable buildings. The places were frequently in the cities' downtown areas; i.e. they largely represent the urbanbackground conditions (although not always). With regard to microscopic analysis, the EAN recommendation is to count at least $10 \%$ of the sample using horizontal or vertical strips (Galán et al., 2014). The actual procedures vary between the countries but generally comply. The counting in 2013 was performed along 12 vertical strips (in most countries), or two to four horizontal traverses (Switzerland, Spain), using a bihourly stratified random sampling (Finland) (Mandrioli and Comtois, 1998). In all cases, the data were expressed as mean daily concentrations (pollen $\mathrm{m}^{-3}$ ).

\subsection{Setup of the simulations}

Simulations followed the standards of MACC regional ensemble (Marécal et al., 2015). The domain spanned from $25^{\circ} \mathrm{W}$ to $45^{\circ} \mathrm{E}$ and from 30 to $70^{\circ} \mathrm{N}$. Each of the seven models was run with its own horizontal and vertical resolutions, which varied from 0.1 to $0.25^{\circ}$ of the horizontal grid cell size, and had from 3 up to 52 vertical layers within the troposphere (Table 1). This range of resolutions is not designed to reproduce local aspects of pollen distribution, instead covering the whole continent and describing the large-scale trans- 

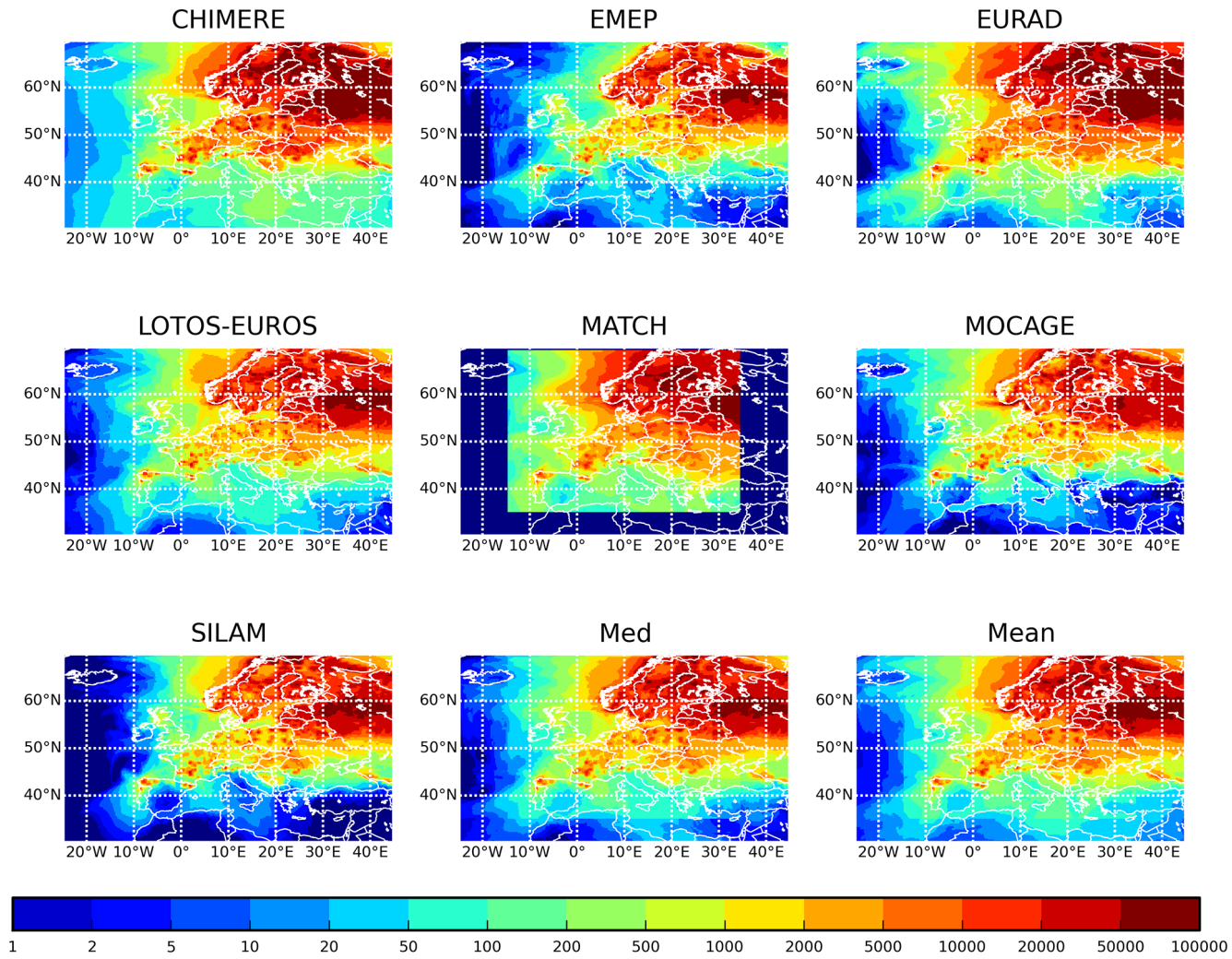

Figure 1. Seasonal pollen index (SPI, sum of daily concentrations) 2013 (pollen day $\mathrm{m}^{-3}$ ).

port events. The limited number of vertical dispersion layers is a compromise allowing for high horizontal resolution. Thick layers are not a major limitation as long as the full vertical resolution of the input meteorological data is used for the evaluation of dispersion parameters (Sofiev, 2002).

In the forecasting regime during the spring of 2013, the time range of the simulations was $96 \mathrm{~h}$ from 00:00 UTC on day 0 (D0) with hourly output on eight vertical levels (surface, 50, 250, 500, 1000, 2000, 3000, and $5000 \mathrm{~m}$ above the surface). After the end of the season, it was reanalysed by most of the models to correct technical problems experienced in the forecasting regime. For the reanalysis simulations (discussed in this paper), the models were run through the whole period without separation into individual forecast cycles. For those models that were not rerun, the first $24 \mathrm{~h}$ of each forecast were used. In all cases, only near-surface concentrations were analysed.

All models considered pollen as an inert water-insoluble particle $22 \mu \mathrm{m}$ in diameter and with density of $800 \mathrm{~kg} \mathrm{~m}^{-3}$ (Bassett et al., 1978; Bucher and Kofler, 2015; Sofiev et al., 2006a)

\section{Results for the flowering season of 2013}

\subsection{Observed peculiarities of the season}

The season of 2013 had three major specifics, which distinguished it from "typical" pollen seasons and, in particular, from the training year of 2010:

- A cold spring resulted in late flowering. In central Europe, the flowering started up to 2-3 weeks later than usual. For instance, 2013 in Switzerland was among the latest years since 1993 (the latest at five stations): 9 days later than in 2010. In Moscow, the cold start of the spring was compensated by its faster progression, so that the early-flowering alder was shifted by about 2 weeks but the birch season was delayed by only a few days. In Lithuania, however, the observed highconcentration time period started 10 days earlier than in 2010, almost simultaneously with France, which was probably caused by early long-range transport events.

- The duration of the season was up to 1 week shorter than usual. Thus, in Switzerland it lasted for $\sim 30$ days (22-35 for different stations) as compared the long-term average of 37 days. In Finland, the difference between the season length in 2010 and in 2013 reached a factor of 2.4 . 
Table 1. Setup of the simulations for the participating models.

\begin{tabular}{|c|c|c|c|c|c|}
\hline Model & $\begin{array}{l}\text { Horizontal dispersion } \\
\text { grid }\end{array}$ & Vertical Dispersion & Meteo input & Meteo grid & Meteo vertical \\
\hline CHIMERE & $0.15^{\circ} \times 0.15^{\circ}$ & 8 levels up to $500 \mathrm{hPa}$ & $\begin{array}{l}\text { ECMWF IFS } 00 \text { operational } \\
\text { forecast, internal preprocessor }\end{array}$ & $0.125^{\circ} \times 0.125^{\circ}$ & IFS vertical: 91 levels \\
\hline EMEP & $0.25^{\circ} \times 0.25^{\circ}$ & 20 levels up to $12 \mathrm{~km}$ & $\begin{array}{l}\text { ECMWF IFS } 00 \text { operational } \\
\text { forecast, internal preprocessor }\end{array}$ & $0.25^{\circ} \times 0.125^{\circ}$ & IFS levels 39-91 up to $100 \mathrm{hPa}$ \\
\hline EURAD & $\begin{array}{l}15 \mathrm{~km} \text { on Lambert con- } \\
\text { formal projection }\end{array}$ & 23 layers up to $100 \mathrm{hPa}$ & WRF based on ECMWF IFS & $\begin{array}{l}15 \mathrm{~km} \text { on Lambert } \\
\text { conformal projection }\end{array}$ & 23 layers up to $100 \mathrm{hPa}$ \\
\hline LOTOS-EUROS & $0.5^{\circ} \times 0.25^{\circ}$ & $\begin{array}{l}3 \text { dynamic layers up } \\
\text { to } 3.5 \mathrm{~km} \text {, surface layer } \\
25 \mathrm{~m}\end{array}$ & $\begin{array}{l}\text { ECMWF IFS } 00 \text { operational } \\
\text { forecast, internal preprocessor }\end{array}$ & $0.5^{\circ} \times 0.25^{\circ}$ & $\begin{array}{l}\text { IFS levels up to } 3.5 \mathrm{~km} \text { (approx. } \\
\text { levels 69-91) }\end{array}$ \\
\hline MATCH & $0.2^{\circ} \times 0.2^{\circ}$ & 52 layers up to $7 \mathrm{~km}$ & $\begin{array}{l}\text { ECMWF IFS } 00 \text { from MARS, } \\
\text { internal preprocessor }\end{array}$ & $0.2^{\circ} \times 0.2^{\circ}$ & IFS vertical: 91 levels \\
\hline MOCAGE & $0.2^{\circ} \times 0.2^{\circ}$ & $\begin{array}{l}47 \text { layers up to } 5 \mathrm{hPa}(7 \\
\text { in } \mathrm{ABL})\end{array}$ & $\begin{array}{l}\text { ECMWF IFS } 00 \text { operational } \\
\text { forecast, internal preprocessor }\end{array}$ & $0.125^{\circ} \times 0.125^{\circ}$ & IFS vertical 91 levels \\
\hline SILAM & $0.15^{\circ} \times 0.15^{\circ}$ & 8 layers up to $6.7 \mathrm{~km}$ & $\begin{array}{l}\text { ECMWF IFS } 00 \text { operational } \\
\text { forecast, internal preprocessor }\end{array}$ & $0.125^{\circ} \times 0.125^{\circ}$ & $\begin{array}{l}\text { IFS levels 40-91 up to } \\
\sim 110 \mathrm{hPa}\end{array}$ \\
\hline
\end{tabular}

- An anomalously low pollen season was recorded in northern Europe and Russia. The seasonal pollen index (SPI: the sum of daily pollen concentrations over the whole season) was 10-1000 times lower than in 2012 and about 10 times weaker than in 2010 (that year was comparatively usual). The SPI in central Europe was moderate, which resulted in an inverse load pattern: the SPI in the north was several tens of times lower than that in the central regions.

These peculiarities presented substantial challenges to the models. The phenological model of the source term has a mechanism that accounts for the season shift, but it still went beyond the verified range. The season strength, however, is currently not a predicted quantity, which made it impossible to capture the anomalously low season in the north.

\subsection{Model results}

All models predicted a quite standard load pattern for the SPI (Fig. 1). Its maximum is located over central Russia and Fennoscandia and the SPI gradually decreases towards the south-west. In central Europe, there is a substantial inhomogeneity of the SPI, which reflects the patchy birch habitat in the region.

Comparison with the observed SPI shows the challenge mentioned above: the very low observed concentrations in the north that were not reproduced by the models (Fig. 2, model predictions are overlaid by the observations - circles coloured following the same palette). This is in contrast with the previous years, particularly 2010, when the observed and modelled patterns were both typical and agreed very well (see example for SILAM, Fig. 3).

An example of the hourly concentrations at noon on 20 April 2013 is shown in Fig. 4. It depicts the middle of

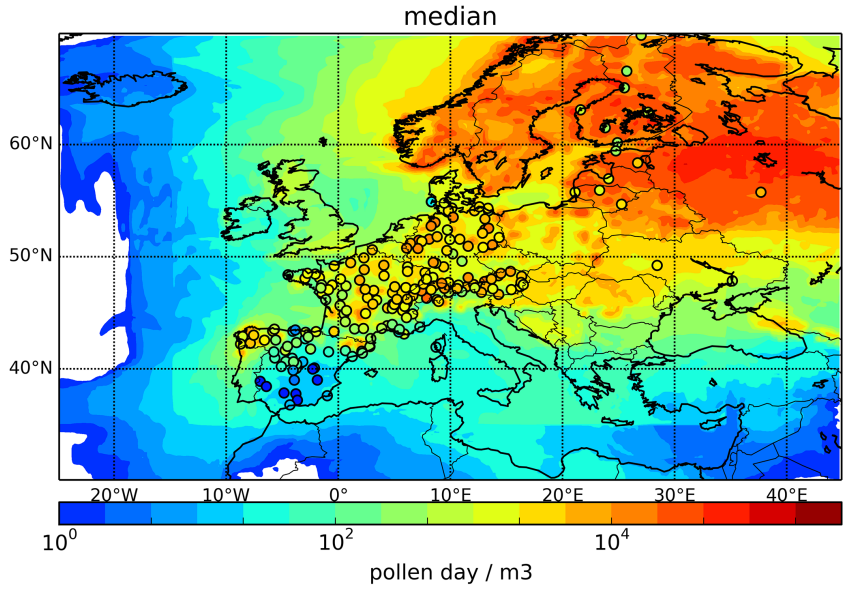

Figure 2. Comparison of SPI for the ensemble median with the observed pollen load (pollen day $\mathrm{m}^{-3}$ ).

the season in central and eastern Europe. The models also showed the long-range transport of pollen to the south that reached Africa in most predictions.

The progress of the season is illustrated in Fig. 5, which depicts 5-day mean concentrations predicted by the ensemble median for four episodes: 1-6, 20-25 April, and 10-15 May and 1-6 June. The season progress in 2013 was quite usual: from the south-west to the north-east of the continent though delayed by up to 2 weeks due to the cold slow spring. The models successfully reproduced this development.

The primary parameters describing the season are its start and end days, often defined as the dates when 5 and $95 \%$ of the cumulative seasonal pollen counts are reached respectively (Fig. 6). Outside the main source areas, the timing of the season is almost completely dictated by the episodes of long-range pollen transport, similar to the southern transport 


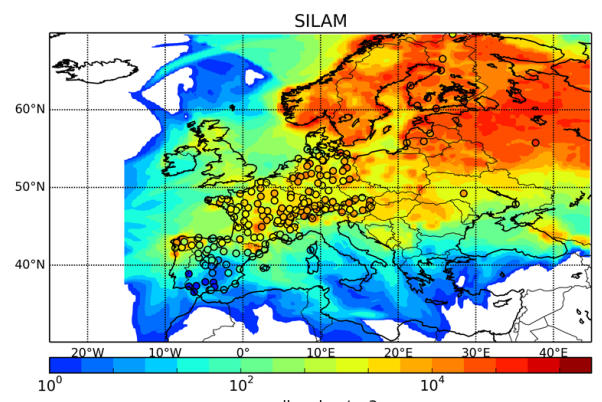

a) 2010

pollen day / $\mathrm{m} 3$



b) 2013

pollen day / $\mathrm{m} 3$

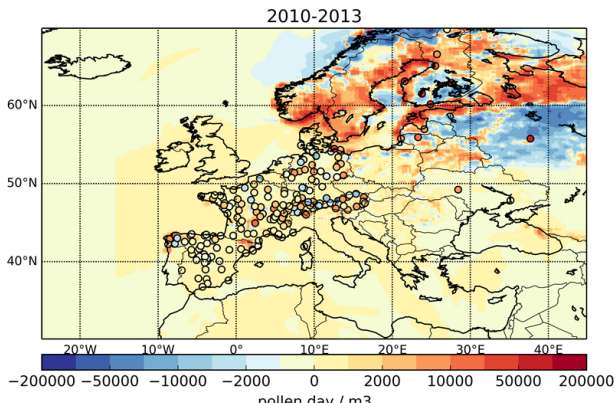

c) $2010-2013$

Figure 3. Seasonal pollen index in 2010 (a) and 2013 (b) and the difference, 2010-2013 (c); observed at the EAN stations (coloured dots) available for the study and predicted by SILAM (fields).
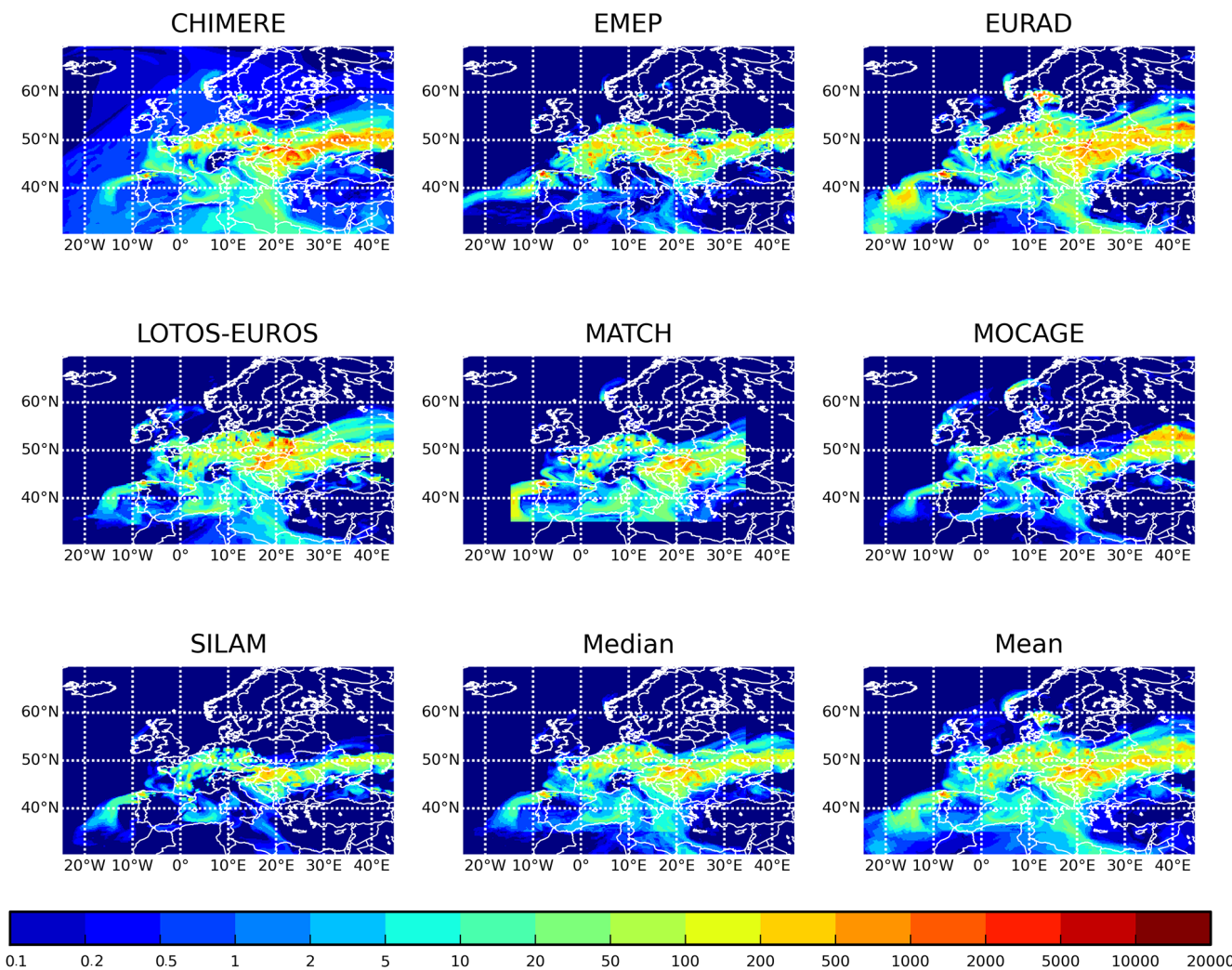

Figure 4. Example of hourly birch pollen concentration maps: 12:00 UTC, 20 April 2013 (pollen m ${ }^{-3}$ ). 

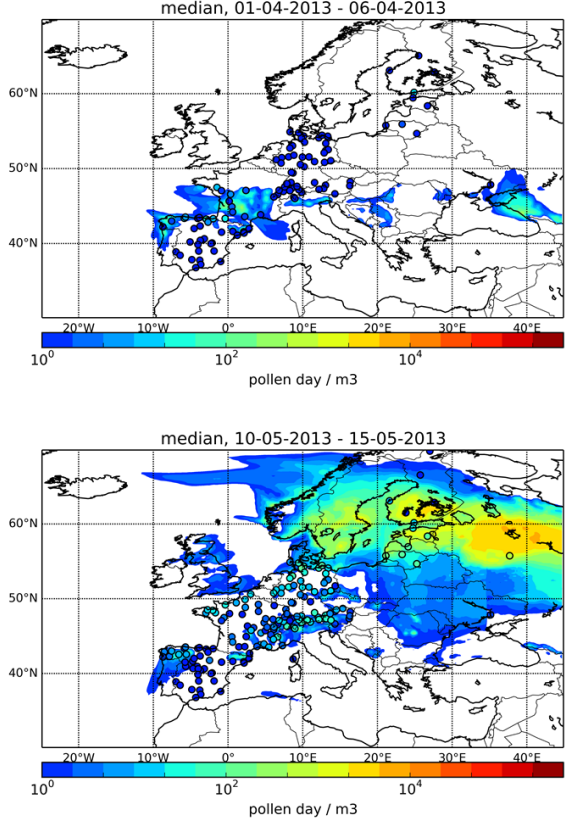
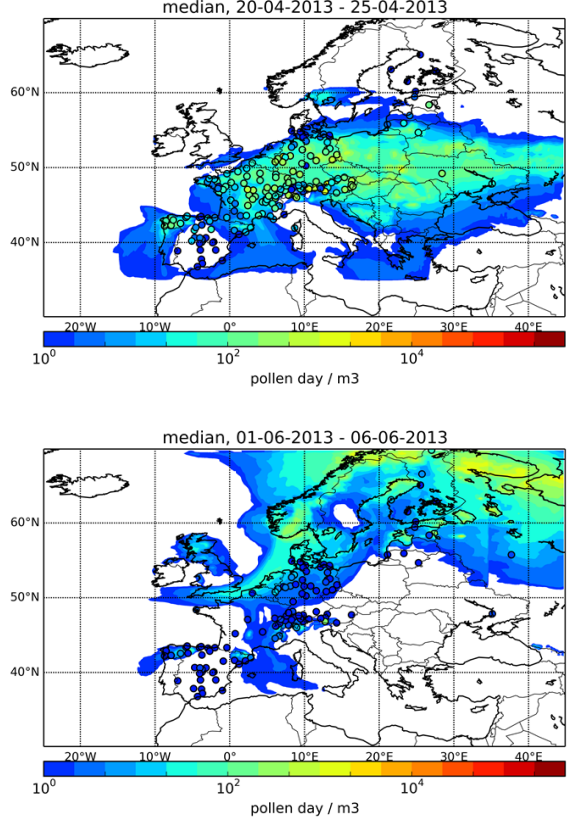

Figure 5. Season progression, ensemble median, and observations: 5-day mean pollen concentrations (pollen $\mathrm{m}^{-3}$ ).

episode shown in Fig. 4. The "fingerprints" of the plumes bringing the first pollen to the regions and those concluding the season are clearly seen in southern Europe, where Spanish stations show a presence of pollen almost as long as in Finland.

With regards to the model-measurement comparison statistics, one has to bear in mind that the time series of pollen concentration represents strongly non-stationary and non-ergodic processes, i.e. the usual statistics (bias, RMSE, correlation, etc.) that all rely on the process stationarity and ergodicity can be computed only within the main season and even then have to be taken with care. A series of such "standard" statistics was computed for the ensemble (Fig. 7), as well as for all individual models (Fig. 8). For the ensemble quality assessment, we used a discrete rank histogram, which is a simple and efficient way to understand the basic properties of the obtained ensemble. The theoretical basis and examples of this histogram and more sophisticated approaches can be found in Candille and Talagrand (2005) and Potempski and Galmarini (2009).

All statistics were calculated for the whole season: 15 March-24 April inclusive. Daily-mean values were used for RMSE and correlation coefficient.

\section{Discussion}

Within this section, the following issues are considered: (i) the ability of the model ensemble to predict the key features of the 2013 birch pollen season, (ii) main uncertainties of the current ensemble, (iii) specific features of the individual ensemble members, and (iv) parameters of the season, for which the use of the ensemble predictions is more beneficial than single-model simulations.

\subsection{Model predictions for the key season parameters}

The most important parameter for the users of pollen forecasts is the season start. Analysis shows (see Figs. 6 and 7) that the ensemble captured the season onset over the majority of central and western Europe with an error of just a couple of days, which is very small. This is in agreement with the source term evaluation by Siljamo et al. (2012).

Both in the north (Finland and Baltic states) and in Spain the pattern is very irregular: the error of the season start (the date when $5 \%$ of the seasonal total is reached) at stations located a couple hundred kilometres from each other can differ by more than a week (Fig. 6). The main reason for such inhomogeneity is that the season start over these areas was largely influenced by remote sources in central Europe and long-range transport. A single episode affecting or pollen cloud passing by the station can result in a few weeks of the apparent-season shift.

The end of the season is more uncertain: the concentrations usually fall more slowly at the season end than they grow at its start, with substantial small-scale variability unresolved by the large-scale simulations. As seen from Fig. 6, the error usually stays within some 5 days but can also reach several weeks, especially in the mountainous regions (Pyrenees, Alps). Fortunately, this parameter is also less important for practical applications.

Representation of the absolute concentrations strongly varies over the European continent (Fig. 7). In its central part 


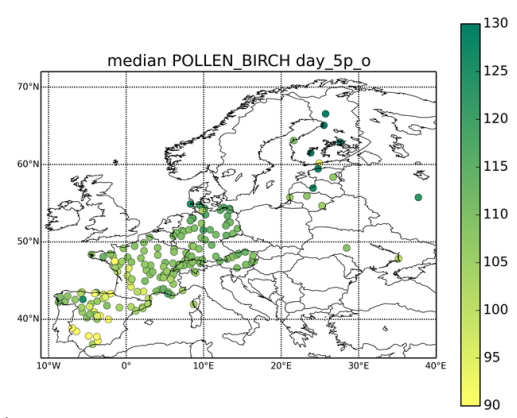

a) $5 \%$ obs ,

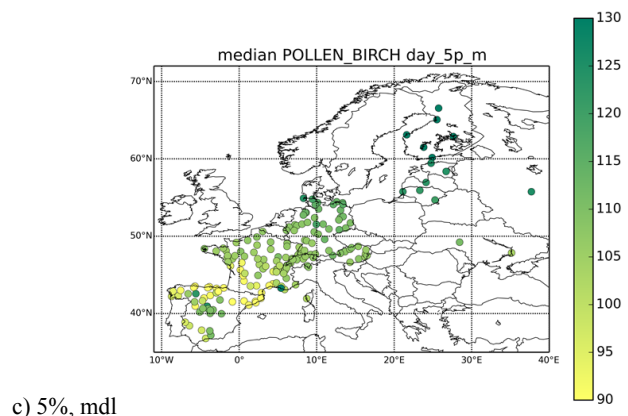

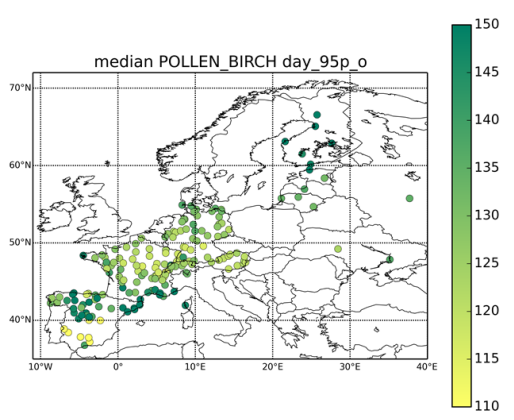

b) $95 \%$ obs

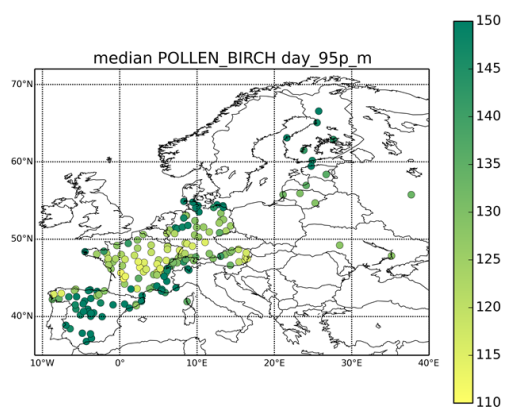

Figure 6. Start (a, c, date of $5 \%$ of the cumulative seasonal total) and end (b, d, date of $95 \%$ of the cumulative seasonal total) of the 2013 pollen season (Julian days), observed (a, b) and predicted by the ensemble median (c, $\mathbf{d})$.

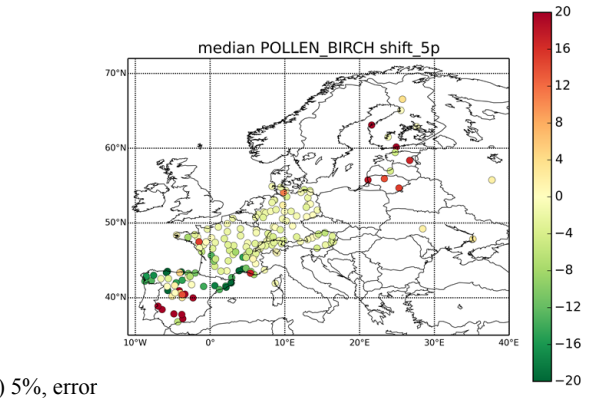

a) $5 \%$, error

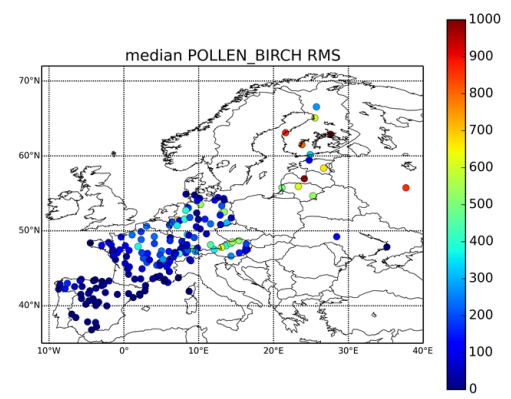

b) Mean bias
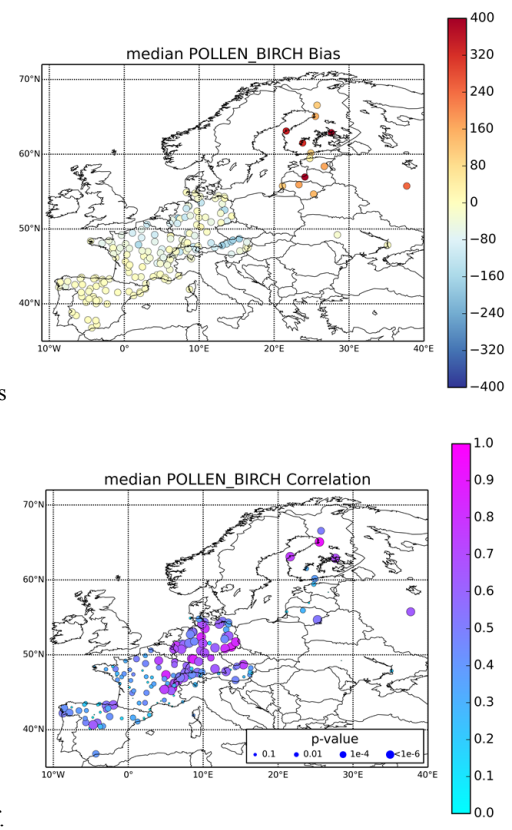

Figure 7. Results of model-measurement comparison for the ensemble median: error in the season start (a, days), seasonal mean bias (b, pollen $\mathrm{m}^{-3}$ ), RMSE (c, pollen $\mathrm{m}^{-3}$ ), correlation coefficient for daily time series (d).

(Germany, Austria, part of France), there is a slight underestimation. In southern France and Spain, it gradually turns to a slight overprediction, suggesting a somewhat too long transport distance in the majority of the models. Finally, in the north all models strongly overpredict. These tenden- cies are practically not dependent on the longitude: available observation points in the east follow the same pattern of very slight overprediction in Ukraine and substantial overstatement in central Russia. The RMSE largely follows the bias field (Fig. 7). 

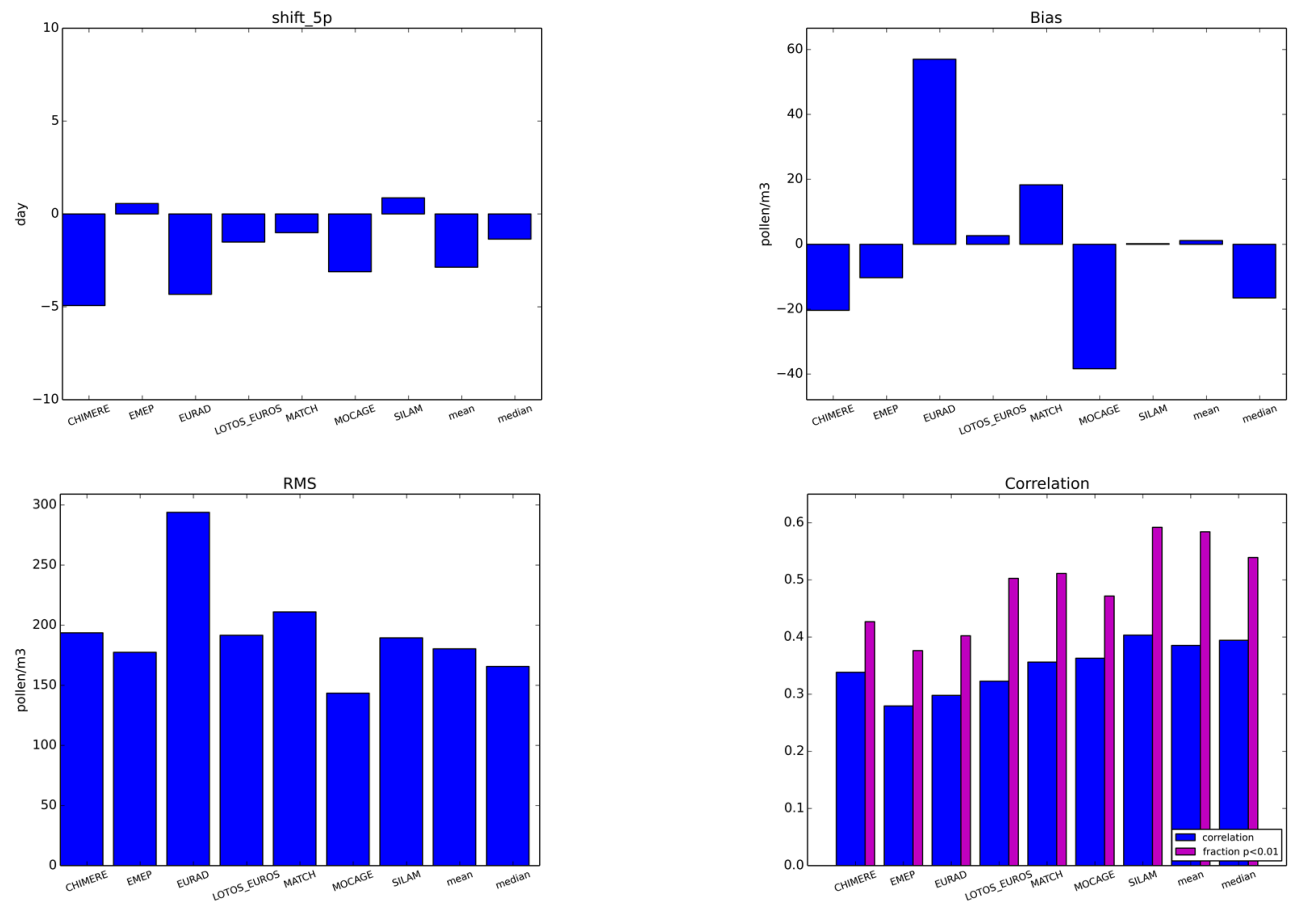

Figure 8. Scores of the individual models: mean over all stations. The parameters are the same as in Fig. 7.

Correlation coefficient (Fig. 7) should be taken with care due to the evident non-stationarity of the process. However, it also highlights central and western Europe (as well as part of northern Europe) as the best-predicted areas. Mountains are the most difficult regions, along with the areas with few birch stands (southern Europe), where the habitat map is highly uncertain. Northern Europe is usually a well-predicted area but not in 2013: as seen from Fig. 7, correlation of time series in the Baltic states and southern part of Finland is quite low. It is high only in Moscow and northern Finland.

\subsection{Main uncertainties of the ensemble}

From the above analysis, one can deduce the main sources of uncertainties of the presented multi-model ensemble: (i) missing interannual variability of the birch productivity, (ii) errors in the mountainous regions, and (iii) birch distribution map.

Currently, there is no model for year-to-year variation of the birch productivity. A few studies reported in literature - e.g. Masaka (2001), Ranta et al. (2008, 2005) - concentrate on predicting the SPI, which is a different quantity significantly affected by the current-year meteorological conditions. The total amount of pollen stored in catkins, in contrast, is decided by the previous-year summer and, to some extent, the following winter conditions. The second complication is that the existing studies are based on a limited number of observation points, which makes it difficult to generalize them to the continental scale. The work is ongoing, but so far the only way to obtain a reliable absolute level of concentrations is via data assimilation performed retrospectively.

The large uncertainties in the mountains originate from the insufficient resolution of both meteorological and dispersion models. As an illustration, the time series for Zams station in Austria (one of the 21 sites excluded from the comparison) shows that all models have shifted the season by several weeks: mid-June instead of late April to early May (Fig. 9). Some models also predicted peaks shortly before the season but these were the pollen plumes from remote sources. This error is exacerbated by a strong underestimation of the absolute values. The reason for the poor performance of all models is the complex-terrain environment with a characteristic width of the valley of barely $2 \mathrm{~km}$. Continental-scale dispersion models, as well as the global meteorological model, all have a resolution 10-20 times coarser than that (Table 1). As a result, the grid-cell-scale temperature is not representative of the valley bottom (it is biased low), which leads to a late predicted start of the season. Moreover, pollen released at the bottom of the narrow valley is usually trapped inside it - in reality - whereas in the models it is mixed over the whole grid cell, which leads to strong underestimation even though the total released amount of pollen is reasonable. 

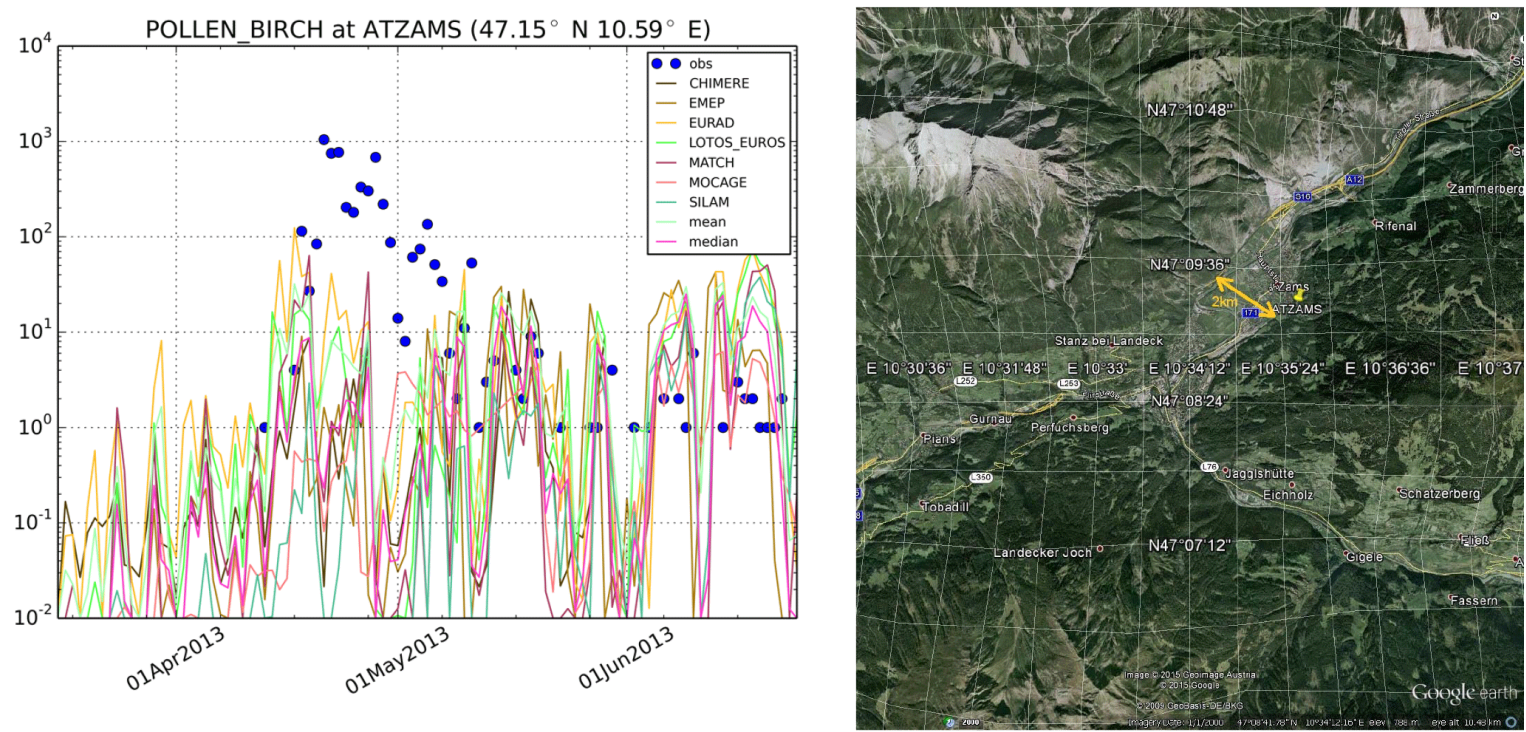

b)

Figure 9. Daily time series for Zams station in Austrian Alps (a, pollen $\mathrm{m}^{-3}$ ) and location of the station (yellow pin) in the $2 \mathrm{~km}$ wide valley (b). Due to the log-scale, zero observations are omitted.

\subsection{Behaviour of individual models}

Following the MACC standards, the setup of the ensemble members was largely harmonised. The emission term was implemented in all models with minimal differences from the one described in Sofiev et al. (2012). The only known deviation was made in SILAM, where the pollen maturation and discharge were separated into two processes controlled by different environmental parameters, similar to Prank et al. (2013) and Zink et al. (2013). However, the impact of this variation at daily averaging is bound to be small. The other parameter that depended on the models was the thickness of the emission injection layer. The recommended layer was from the surface up to a height of $50 \mathrm{~m}$ but the model's geometry affected it.

Meteorological input data were the same - the IFS forecasts. Meteorological data pre-processing was based on comparatively simple diagnostic procedures embedded in all models except for EURAD, which used the WRF model nested into IFS. The tasks of the preprocessors were (i) to derive the boundary layer characteristics missing from the IFS and (ii) for some models to re-diagnose the vertical wind component or refine the 3-D wind fields to ensure satisfaction of the continuity equation.

In light of this, the differences between the model predictions visible in Figs. 1, 4, and 8 should be mainly attributed to (i) model treatment of the 3-D pollen transport, (ii) vertical mixing, and (iii) removal mechanisms.

In general, the model results are quite similar and the main features of the pollen distribution are clearly visible in the individual-model patterns. On a closer look, one can see a few tendencies, such as (i) higher-than-average concentrations predicted by EURAD, (ii) lower-than-average values of MOCAGE, (iii) longer lifetime and farther atmospheric transport of CHIMERE, (iv) the shortest transport distance indicated by SILAM (Fig. 1), (v) about $10 \%$ lowerthan-others correlation coefficient of EMEP, EURAD, and LOTOS-EUROS (Fig. 8), and (vi) a general tendency of a couple of days early start of the season for most models except for CHIMERE (6 days too early) and for EMEP and SILAM (1-2 days late season) (Fig. 8).

Interpretation of these tendencies is not unequivocal but some of them are connected. For instance, the season start is largely controlled by the possible long-range transport episodes, so that the model reporting the longest pollen transport (CHIMERE) predicts a too-early season start, especially in remote regions. Conversely, SILAM, with its shortest travelling distance, would report fewer such events, leading to later season onset. The same is true for EMEP, which also reported quite a short transport distance. The high predictions of EURAD lead to somewhat higher RMSE and low predictions of MOCAGE lead to lower RMSE, owing to the high bias of all the models in the north.

In a few cases, available observational information enables evaluation of these features. In particular, a quick north-tosouth reduction of the observed SPI in Spain (Fig. 2) suggests that the transport distance of pollen is indeed short (see also Fig. 3). This would also reduce the early bias of the season start shown by most models. Secondly, the approximately $10 \%$ higher correlation coefficient of SILAM might possibly be attributed to the more articulated impact of local birch since the long-range effects are of lower importance for 


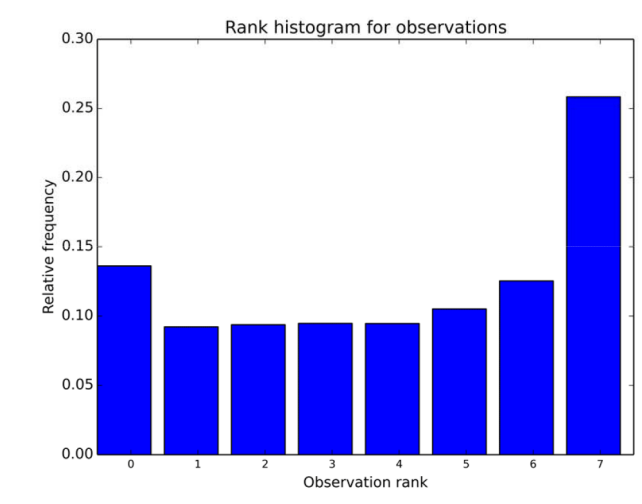

a) Talagrand diagram

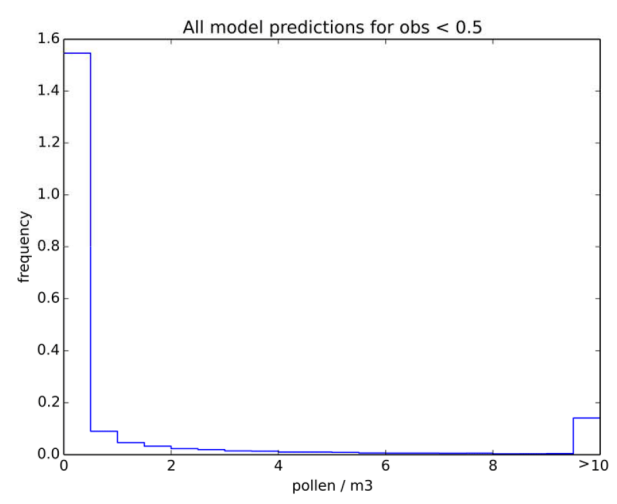

b) Model predictions for near-zero measurements

Figure 10. Ensemble characteristics: (a) Talagrand diagram for the constructed ensemble (daily concentration statistics) and (b) histogram of model predictions when observations were below the detection limit 0.5 pollen $\mathrm{m}^{-3}$.

that model, owing to its short transport distance. These observations might also be projected to the resuspension process suggested by Helbig et al. (2004) but never explicitly verified or confirmed, as pointed out by Sofiev et al. (2012). Among the seven models, only CHIMERE included it, which may be one of the reasons for its longer transport distance. The above comparison raises further concerns regarding this process.

Evaluation of absolute concentrations is hardly conclusive due to the very specific season and overall uncertainty of this parameter.

\subsection{Ensemble added value}

Compilation of the multi-model ensemble out of individual models has proven to be beneficial. As seen from Fig. 8, the ensemble median, together with the ensemble mean and SILAM, has the highest correlation coefficient. The ensemble also showed among the shortest shifts of the season start and among the smallest RMSEs. Its robustness to outliers also turned out to be a very strong asset for pollen forecasting, which is a comparatively new area of modelling and has many unknowns in the governing processes.

However, the ensemble can only be as good as the majority of the individual models. As follows from the rank histogram (the Talagrand diagram, Fig. 10, left panel), the current ensemble is not perfect. The diagram shows the generally underestimating ensemble (tendency towards higher ranks of the observations) simultaneously with a fraction of observations being substantially overestimated (zeroth rank is also frequent). The latter feature is due not only to the northern sites (albeit few) but also to southern Spanish stations, where the overestimation is also systematic. Moderate underestimation takes place mainly in central Europe (Fig. 2), where most of the stations are located. However, even this imperfect ensemble outperformed most of the individual models.

Construction of the rank histogram for pollen faced a methodological problem: pollen concentrations long before and long after the flowering season are 0. One should also bear in mind the quite high detection limit for the microscopic analysis (about 0.5 pollen $\mathrm{m}^{-3}$ for daily mean), which increases the frequency of observed zero concentrations. In 2013 , about $15 \%$ of observations and $10-15 \%$ of model predictions were below this limit. For the all-zero cases (zero observations and below-detection-limit bulk/all of the models), determination of the observation rank is meaningless: the ensemble variance collapses and its mean matches the observations perfectly. Neither of these cases can be ignored: they have clear physical meaning and manifest excellent ensemble behaviour. Therefore, for such cases the observation rank in Fig. 10 was picked as a random number from 0 to 7 , i.e. it corresponded to a "perfect" ensemble. To illustrate the ensemble behaviour when the observations were below the detection limit, the histogram of the corresponding model values is shown in Fig. 10, right panel. As one can see, in over $80 \%$ of zero observations models also showed the concentrations below 0.5 pollen $\mathrm{m}^{-3}$. This peculiarity has to be kept in mind for future pollen-related ensembles.

\section{Summary}

The first-ever multi-model ensemble was created for predicting the concentrations of birch pollen in Europe. The ensemble was constructed from seven European atmospheric chemistry transport models of MACC and follows the main rules of the MACC regional ensemble: the models share the same source term, use the same meteorological input, and cover the MACC domain with similar resolution.

The ensemble was evaluated against the observational data of European Aeroallergen Network for the year 2013 and the basic statistical indicators were computed for each individual ensemble member, as well as for the ensemble mean and median. 
The ensemble demonstrated good skills in predicting several main characteristics of the pollen season of 2013: the season start and propagation, the pollen distribution pattern in central, eastern, and southern Europe, and characteristic concentrations over these regions. The season timing was captured despite the anomalously late flowering due to the cold spring of 2013.

Representation of the pollen concentrations in northern Europe, the Baltic states, and central Russia was affected by the anomalously low flowering intensity in 2013. As a result, all models had strongly overestimated pollen levels there. This was in contrast to the usual pollen distribution pattern in Europe, such as the one of the quite typical year of 2010, which was reproduced much better.

The experiment showed the high added value of the ensemble. For most of the participating models this was the first experience of pollen simulations, which affected the reliability of their results. The ensemble median proved to be robust to the outliers, finally showing among the highest correlation coefficients and one of the smallest errors in the season timing and RMSEs.

The main areas of improvement referred to the interannual variation of the birch productivity as well as to the representation of the flowering timing in the complex-terrain conditions.

Acknowledgements. The work was performed within the scope of the FP-7 MACC-II project. The birch source term is developed within the scope of the Academy of Finland POLLEN and APTA projects. Observational data were provided by national pollen monitoring of Austria, Estonia, Germany, Finland, France, Latvia, Lithuania, Russia, Spain, Switzerland, and Ukraine, members of the European Aeroallergen Network.

Edited by: S. Galmarini

\section{References}

Atkinson, M. D.: Betula pendula Roth (B. verrucosa Ehrh.) and B. pubescens Ehrh. J. Ecol., 80, 837-870, 1992.

Baklanov, A. and Sorensen, J. H.: Parameterisation of radionuclide deposition in atmospheric long-range transport modelling, Phys. Chem. Earth, Pt. B, 26, 787-799, 2001.

Bassett, I. J., Crompton, C. W., and Parmelee, J. A.: An Atlas of Airborne Pollen Fungus Spores of Canada. Research Branch Canada Department of Agriculture, Ottawa, 1978.

Bechtold, P., Bazile, E., Guichard, F., Mascart, P., and Richard, E.: A mass-flux convection scheme for regional and global models, Q. J. Roy. Meteorol. Soc., 127, 869-886, 2001.

Belmonte, J., Vendrell, M., Roure, J., Vidal, J., Botey, J., and Cadahía, A.: Levels of Ambrosia pollen in the atmospheric spectra of Catalan aerobiological stations, Aerobiologia (Bologna), 16, 93-99, 2000.
Bott, A.: A positive definite advection scheme obtained by nonlinear renormalization of the advective fluxes, Mon. Weather Rev., 117, 1006-1016, 1989.

Bousquet, P.-J., Chinn, S., Janson, C., Kogevinas, M., Burney, P., and Jarvis, D.: Geographical variation in the prevalence of positive skin tests to environmental aeroallergens in the European Community Respiratory Health Survey I. Allergy, 62, 301-309, doi:10.1111/j.1398-9995.2006.01293.x, 2007.

Bucher, E. and Kofler, V.: Pollen Atlas, Biol. Lab. State Agency Environ, Bozen, available at: https://www.polleninfo. org/FI/fi/allergy-infos/aerobiologics/pollen-atlas.html, last access: 6 July 2015.

Candille, G. and Talagrand, O.: Evaluation of probabilistic prediction systems for a scalar variable, Q. J. Roy. Meteorol. Soc., 131, 2131-2150, doi:10.1256/qj.04.71, 2005.

Corden, J. M., Stach, A., and Milligton, W.: A comparison of Betula pollen season at two European sites; Derby, United Kingdom and Poznan, Poland (1995-1999), Aerobiologia (Bologna), 18, 5354, 2002.

Damialis, A. and Gioulekas, D.: Transport of airborne pollen into the city of Thessaloniki?: the effects of wind direction, speed and persistence, Int. J. Biometeorol., 49, 139-145, doi:10.1007/s00484-004-0229-z, 2005.

Efstathiou, C., Isukapalli, S., and Georgopoulos, P.: A mechanistic modeling system for estimating large-scale emissions and transport of pollen and co-allergens, Atmos. Environ., 45, 2260-2276, doi:10.1016/j.atmosenv.2010.12.008, 2011.

Elbern, H., Strunk, A., Schmidt, H., and Talagrand, O.: Emission rate and chemical state estimation by 4-dimensional variational inversion, Atmos. Chem. Phys., 7, 3749-3769, doi:10.5194/acp7-3749-2007, 2007.

Erdtman, G.: Pollen-statistics: A new research method in paleoecology, Science, 73, 399-401, 1931.

Erdtman, G.: Pollen statistics: A botanical and geological research method, in: Pollen Grains, edited by: Wodehouse, R. P., 110-125, 1935.

Erdtman, G.: Pollen grains recovered from the atmosphere over the Atlantic, Medd. Göteborgs Bot. Trädgård, 12, 186-196, 1937.

Galán, C., Smith, M., Thibaudon, M., Frenguelli, G., Oteros, J., Gehrig, R., Berger, U., Clot, B., Brandao, R., and Group, E. Q. W.: Pollen monitoring: minimum requirements and reproducibility of analysis, Aerobiologia (Bologna), 30, 385-395, 2014.

Galperin, M. V: The Approaches to Correct Computation of Airborne Pollution Advection, in: Problems of Ecological Monitoring and Ecosystem Modelling. XVII, Gidrometeoizdat, St. Petersburg, 54-68, 2000 (in Russian).

Giorgi, F. and Chameides, W. L.: Rainout lifetimes of highly soluble aerosols and gases as inferred from simulations with a general circulation model, J. Geophys. Res., 91, 14367-14376, 1986.

Gregory, P. H.: The microbiology of the atmosphere, Interscience, New York, 1961.

Hass, H., Jakobs, H. J., and Memmesheimer, M.: Analysis of a regional model (EURAD) near surface gas concentration predictions using observations from networks, Meteorol. Atmos. Phys., 57, 173-200, 1995.

Heinzerling, L. M., Burbach, G. J., Edenharter, G., Bachert, C., Bindslev-Jensen, C., Bonini, S., Bousquet, J., Bousquet-Rouanet, L., Bousquet, P. J., Bresciani, M., Bruno, A., Burney, P., Canonica, G. W., Darsow, U., Demoly, P., Durham, S., Fokkens, W. J., 
Giavi, S., Gjomarkaj, M., Gramiccioni, C., Haahtela, T., Kowalski, M. L., Magyar, P., Muraközi, G., Orosz, M., Papadopoulos, N. G., Röhnelt, C., Stingl, G., Todo-Bom, A., Von Mutius, E., Wiesner, A., Wöhrl, S., and Zuberbier, T.: GA2LEN skin test study I: GA ${ }^{2}$ LEN harmonization of skin prick testing: novel sensitization patterns for inhalant allergens in Europe, Allergy, 64, 1498-1506, 2009.

Helbig, N., Vogel, B., Vogel, H., and Fiedler, F.: Numerical modelling of pollen dispersion on the regional scale, Aerobiologia (Bologna), 3, 3-19, 2004.

Hirst, J. M.: An automatic volumetric spore trap, Ann. Appl. Biol., 39, 257-265, 1954.

Hjelmroos, M.: Long-distance transport of Betula pollen grains and allergic symptoms, Aerobiologia (Bologna), 8, 231-236, 1992.

Holtslag, A. A. and Nieuwstadt, F. T. M.: Scaling the atmospheric boundary layer. Bound. Layer Meteorol. 36, 201-209, 1986.

Jäger, S., Mandroli, P., Spieksma, F., Emberlin, J., Hjelmroos, M., Rantio-Lehtimaki, A., and Al, E.: News, Aerobiologia (Bologna), 11, 69-70, 1995.

Josse, B., Simon, P., and Peuch, V.: Radon global simulations with the multiscale chemistry and transport model MOCAGE, Tellus B, 56, 339-356, 2004.

Kouznetsov, R. and Sofiev, M.: A methodology for evaluation of vertical dispersion and dry deposition of atmospheric aerosols, J. Geophys. Res., 117, D01202, doi:10.1029/2011JD016366, 2012.

Kukkonen, J., Olsson, T., Schultz, D. M., Baklanov, A., Klein, T., Miranda, A. I., Monteiro, A., Hirtl, M., Tarvainen, V., Boy, M., Peuch, V.-H., Poupkou, A., Kioutsioukis, I., Finardi, S., Sofiev, M., Sokhi, R., Lehtinen, K. E. J., Karatzas, K., San José, R., Astitha, M., Kallos, G., Schaap, M., Reimer, E., Jakobs, H., and Eben, K.: A review of operational, regional-scale, chemical weather forecasting models in Europe, Atmos. Chem. Phys., 12, 1-87, doi:10.5194/acp-12-1-2012, 2012.

Laatikainen, T., von Hertzen, L., Koskinen, J.-P., Makela, M. J., Jousilahti, P., Kosunen, T. U., Vlasoff, T., Ahlstrom, M., Vartiainen, E., and Haahtela, T.: Allergy gap between Finnish and Russian Karelia on increase, Allergy, 66, 886-892, 2011.

Langner, J., Bergström, R., and Pleijel, K.: European scale modeling of sulphur, oxidized nitrogen and photochemical oxidants, Model dependent development av evaluation for the 1994 growing season, Norkoping, 1998.

Latalova, M., Miętus, M., and Uruska, A.: Seasonal variations in the atmospheric Betula pollen count in Gdañsk (southern Baltic coast) in relation to meteorological parameters, Aerobiologia (Bologna), 18, 33-43, 2002.

Lindgren, D., Paule, L., Shen, X.-H., Yazdani, R., Segerstrom, U., Wallin, J.-E., and Lejdebro, M. L.: Can viable pollen carry Scotch pine genes over long distances?, Grana, 34, 64-69, 1995.

Linkosalo, T., Ranta, H., Oksanen, A., Siljamo, P., Luomajoki, A., Kukkonen, J., and Sofiev, M.: A double-threshold temperature sum model for predicting the flowering duration and relative intensity of Betula pendula and B. pubescens, Agr. Forest Meteorol., 150, 1579-1584, doi:10.1016/j.agrformet.2010.08.007, 2010.

Louis, J.-F.: A parametric model of vertical eddy fluxes in the atmosphere, Bound. Lay.-Meteorol., 17, 187-202, 1979.

Mahura, A., Korsholm, U., Baklanov, A., and Rasmussen, A.: Elevated birch pollen episodes in Denmark?: contributions from remote sources, Aerobiologia (Bologna), 23, 171-179, doi:10.1007/s10453-007-9061-3, 2007.

Mahura, A., Baklanov, A., and Korsholm, U.: Parameterization of the birch pollen diurnal cycle, Aerobiologia (Bologna), 25, $203-$ 208, doi:10.1007/s10453-009-9125-7, 2009.

Mandrioli, P. and Comtois, P. V. L. (Eds.): Methods in Aerobiology, Pitagora Editrice, Bologna, 1998.

Marécal, V., Peuch, V.-H., Andersson, C., Andersson, S., Arteta, J., Beekmann, M., Benedictow, A., Bergström, R., Bessagnet, B., Cansado, A., Chéroux, F., Colette, A., Coman, A., Curier, R. L., Denier van der Gon, H. A. C., Drouin, A., Elbern, H., Emili, E., Engelen, R. J., Eskes, H. J., Foret, G., Friese, E., Gauss, M., Giannaros, C., Guth, J., Joly, M., Jaumouillé, E., Josse, B., Kadygrov, N., Kaiser, J. W., Krajsek, K., Kuenen, J., Kumar, U., Liora, N., Lopez, E., Malherbe, L., Martinez, I., Melas, D., Meleux, F., Menut, L., Moinat, P., Morales, T., Parmentier, J., Piacentini, A., Plu, M., Poupkou, A., Queguiner, S., Robertson, L., Rouill, L., Schaap, M., Segers, A., Sofiev, M., Thomas, M., Timmermans, R., Valdebenito, Á., van Velthoven, P., van Versendaal, R., Vira, J., and Ung, A.: A regional air quality forecasting system over Europe: the MACC-II daily ensemble production, Geosci. Model Dev. Discuss., 8, 2739-2806, doi:10.5194/gmdd-8-27392015, 2015.

Martet, M., Peuch, V.-H., Laurent, B. B. M., and Bergametti, G.: Evaluation of long-range transport and deposition of desert dust with the CTM Mocage, Tellus B, 61, 449-463, 2009.

Masaka, K.: Modelling the Masting Behaviour of Betula platyphylla var. japonica using the Resource Budget Model, Ann. Bot., 88, 1049-1055, doi:10.1006/anbo.2001.1547, 2001.

Memmesheimer, M., Friese, E., Ebel, A., Jakobs, H. J., Feldmann, H., Kessler, C., and Piekorz, G.: Long-term simulations of particulate matter in Europe on different scales using sequential nesting of a regional model, Int. J. Environ. Pollut., 22, 108-132, 2004.

Menut, L., Bessagnet, B., Khvorostyanov, D., Beekmann, M., Blond, N., Colette, A., Coll, I., Curci, G., Foret, G., Hodzic, A., Mailler, S., Meleux, F., Monge, J.-L., Pison, I., Siour, G., Turquety, S., Valari, M., Vautard, R., and Vivanco, M. G.: CHIMERE 2013: a model for regional atmospheric composition modelling, Geosci. Model Dev., 6, 981-1028, doi:10.5194/gmd6-981-2013, 2013.

OECD: Consensus document on the biology of European white birch (Betula pendula Roth), Series on harmonisation of regulatory oversight in biotechnology, OECD Report ENV/JM/MONO(2003)12, Paris, available at: http://www.oecd. org/science/biotrack/46815768.pdf (last access: 19 July 2015), 2003.

Pauling, A., Rotach, M. W., Gehrig, R., and Clot, B.: A method to derive vegetation distribution maps for pollen dispersion models using birch as an example, Int. J. Biometeorol., 56, 949-958, doi:10.1007/s00484-011-0505-7, 2012.

Petroff, A. and Zhang, L.: Development and validation of a size-resolved particle dry deposition scheme for application in aerosol transport models, Geosci. Model Dev., 3, 753-769, doi:10.5194/gmd-3-753-2010, 2010.

Potempski, S. and Galmarini, S.: Est modus in rebus: analytical properties of multi-model ensembles, Atmos. Chem. Phys., 9, 9471-9489, doi:10.5194/acp-9-9471-2009, 2009. 
Prank, M., Chapman, D. S., Bullock, J. M., Belmonte, J., Berger, U., Dahl, A., Jäger, S., Kovtunenko, I., Magyar, D., Niemelä, S., Rantio-Lehtimäki, A., Rodinkova, V., Sauliene, I., Severova, E., Sikoparija, B., and Sofiev, M.: An operational model for forecasting ragweed pollen release and dispersion in Europe, Agr. Forest Meteorol., 182-183, 43-53, doi:10.1016/j.agrformet.2013.08.003, 2013.

Ranta, H. and Satri, P.: Synchronized inter-annual fluctuation of flowering intensity affects the exposure to allergenic tree pollen in North Europe, Grana, 46, 274-284, 2007.

Ranta, H., Oksanen, A., Hokkanen, T., Bondesman, K., and Heino, S.: Masting by Betula-species?; applying the resource budget model to north European data sets, Int. J. Biometeorol., 49, 146151, doi:10.1007/s00484-004-0228-0, 2005.

Ranta, H., Hokkanen, T., Linkosalo, T., Laukkanen, L., Bondesman, K., and Oksanen, A.: Male flowering of birch?: Spatial synchronization, year-to-year variation and relation of catkin numbers and airborne pollen counts, For. Ecol. Manage., 255, 643-650, doi:10.1016/j.foreco.2007.09.040, 2008.

Ranta, H., Siljamo, P., Oksanen, A., Sofiev, M., Linkosalo, T., Bergmann, K.-C., Bucher, E., Ekebom, A., Emberlin, J., Gehrig, R., Hallsdottir, M., Jato, V., Jäger, S., Myszkowska, D., Paldy, A., Ramfjord, H., Severova, E., and Thibaudon, M.: Aerial and annual variation of birch pollen loads and a modelling system for simulating and forecasting pollen emissions and transport at an European scale, Aerobiol. Monogr., 1, 115-131, 2011.

Rantio-Lehtimaki, A.: Short, medium and long range transported airborne particles in viability and antigenicity analyses, Aerobiologia (Bologna), 10, 175-181, 1994.

Raynor, G. S., Ogden, E. C., and Hayes, J. V.: Dispersion and deposition of ragweed pollen from experimental sources, J. Appl. Meteorol. Climatol., 9, 885-895, 1970.

Robertson, L. and Langner, J.: An Eulerian Limited-Area Atmospheric Transport Model, J. Appl. Meteorol., 38, 190-210, 1999.

Rönmark, E., Bjerg, A., Perzanowski, M., Platts-Mills, T., and Lundbäck, B.: Major increase in allergic sensitization in school children from 1996 to 2006 in Northern Sweden, J. Allergy Clin. Immunol., 124, 1-19, doi:10.1016/j.jaci.2009.05.011, 2009.

Schaap, M., Timmermans, R. M. A., Roemer, M., Boersen, G. A. C., Builtjes, P. J. H., Sauter, F. J., Velders, G. J. M., and Beck, J. P.: The LOTOS-EUROS model: Description, validation and latest developments, Int. J. Environ. Pollut., 32, 270-290, 2008.

Scott, B. C.: Parameterization of sulphate removal by precipitation, J. Appl. Meteorol., 17, 11275-11389, 1979.

Seinfeld, J. H. and Pandis, S. N.: Atmospheric Chemistry and Physics, 1st Edn., Wiley, New York, 1998.

Siljamo, P., Sofiev, M., Severova, E., Ranta, H., and Polevova, S.: On influence of long-range transport of pollen grains onto pollinating seasons, in: Developments in Environmental Science, edited by: Borrego, C. and Renner, E., 6. Air Polution Modelling and Its Applications XVIII, 708-716, doi:10.1016/S14748177(70)06074-3, 2006

Siljamo, P., Sofiev, M., Linkosalo, T., Ranta, H., and Kukkonen, J.: Development and application of biogenic emission term as a basis of long-range transport of allergenic pollen, in: NATO Science for Piece and Security Serties C: Environmental Security, edited by: Borrego, C. and Miranda, A. I., Air Pollution Modelling and Its Application, XIX, Springer, Springer-Verlag Berlin, 154-162, 2008a.
Siljamo, P., Sofiev, M., Ranta, H., Linkosalo, T., Kubin, E., Ahas, R., Genikhovich, E., Jatczak, K., Jato, V., Nekovar, J., Minin, A., Severova, E., and Shalabova, V.: Representativeness of pointwise phenological Betula data collected in different parts of Europe, Glob. Ecol. Biogeogr., 17, 489-502, doi:10.1111/j.14668238.2008.00383.x, 2008b.

Siljamo, P., Sofiev, M., Severova, E., Ranta, H., Kukkonen, J., Polevova, S., Kubin, E., and Minin, A.: Sources, impact and exchange of early-spring birch pollen in the Moscow region and Finland, Aerobiologia (Bologna), 24, 211-230, doi:10.1007/s10453-008-9100-8, 2008c.

Siljamo, P., Sofiev, M., Filatova, E., Grewling, L., Jäger, S., Khoreva, E., Linkosalo, T., Ortega Jimenez, S., Ranta, H., Rantio-Lehtimäki, A., Svetlov, A., Veriankaite, L., Yakovleva, E., and Kukkonen, J.: A numerical model of birch pollen emission and dispersion in the atmosphere. Model evaluation and sensitivity analysis, Int. J. Biometeorol., 57, 125-136, doi:10.1007/s00484-012-0539-5, 2012.

Simpson, D., Fagerli, H., Jonson, J. E., Tsyro, S., Wind, P., and Tuovinen, J.-P.: Transboundary Acidification, Eutrophication and Ground Level Ozone in Europe, Part 1: Unified EMEP Model Description, EMEP Report 1/2003, Oslo, 2003.

Simpson, D., Benedictow, A., Berge, H., Bergström, R., Emberson, L. D., Fagerli, H., Flechard, C. R., Hayman, G. D., Gauss, M., Jonson, J. E., Jenkin, M. E., Nyíri, A., Richter, C., Semeena, V. S., Tsyro, S., Tuovinen, J.-P., Valdebenito, Á., and Wind, P.: The EMEP MSC-W chemical transport model - technical description, Atmos. Chem. Phys., 12, 7825-7865, doi:10.5194/acp-127825-2012, 2012.

Skjøth, C. A., Sommer, J., Stach, A., Smith, M., and Brandt, J.: The long-range transport of birch (Betula) pollen from Poland and Germany causes significant pre-season concentrations in Denmark, Clin. Exp. Allergy, 37, 1204-1212, doi:10.1111/j.13652222.2007.02771.x, 2007.

Skjøth, C. A., Sommer, J., Brandt, J., Hvidberg, M., Geels, C., Hansen, K. M., Hertel, O., Frohn, L. M., and Christensen, J. H.: Copenhagen - a significant source of birch (Betula) pollen?, Int. J. Biometeorol., 52, 453-462, doi:10.1007/s00484-007-0139-y, 2008.

Skjøth, C. A., Smith, M., Brandt, J., and Emberlin, J.: Are the birch trees in Southern England a source of Betula pollen for North London?, Int. J. Biometeorol., 53, 75-86, doi:10.1007/s00484008-0192-1, 2009.

Smith, M., Skjøth, C. A., Myszkowska, D., Uruska, A., Puc, M., Stach, A., Balwierz, Z., Chlopek, K., Piotrowska, K., Kasprzyk, I., and Brandt, J.: Long-range transport of Ambrosia pollen to Poland, Environ. Res., 148, 1402-1411, doi:10.1016/j.agrformet.2008.04.005, 2008.

Smith, M., Jäger, S., Berger, U., Sikoparija, B., Hallsdottir, M., Sauliene, I., Bergmann, K.-C., Pashley, C.H., de Weger, L., Majkowska-Wojciechowska, B., Rybníček, O., Thibaudon, M., Gehrig, R., Bonini, M., Yankova, R., Damialis, A., Vokou, D., Gutiérrez Bustillo, A. M., Hoffmann-Sommergruber, K., and van Ree, R.: Geographic and temporal variations in pollen exposure across Europe, Allergy, 69, 913-923, doi:10.1111/all.12419, 2014.

Sofiev, M.: Extended resistance analogy for construction of the vertical diffusion scheme for dispersion models, J. Geophys. Res., 107, ACH 10-1-ACH 10-8, doi:10.1029/2001JD001233, 2002. 
Sofiev, M. and Bergmann, K.-C. (Eds.): Allergenic pollen. A review of production, release, distribution and health impact, SpringerVerlag Berlin, Heidelberg, 2013.

Sofiev, M., Siljamo, P., Ranta, H., and Rantio-Lehtimaki, A.: Towards numerical forecasting of long-range air transport of birch pollen: theoretical considerations and a feasibility study, Int. J. Biometeorol., 50, 392-402, doi:10.1007/s00484-006-0027-x, $2006 \mathrm{a}$.

Sofiev, M., Siljamo, P., Valkama, I., Ilvonen, M., and Kukkonen, J.: A dispersion modelling system SILAM and its evaluation against ETEX data, Atmos. Environ., 40, 674-685, doi:10.1016/j.atmosenv.2005.09.069, 2006b.

Sofiev, M., Galperin, M. V., and Genikhovich, E.: Construction and evaluation of Eulerian dynamic core for the air quality and emergency modeling system SILAM, in: NATO Science for Piece and Security Serties C: Environmental Security, edited by: Borrego, C. and Miranda, A. I., Air Pollution Modelling and Its Application, XIX, Springer-Verlag Berlin, 699-701, 2008.

Sofiev, M., Siljamo, P., Ranta, H., and Linkosalo, T.: A numerical model of birch pollen emission and dispersion in the atmosphere, Description of the emission module, Int. J. Biometeorol., 57, 4558, doi:10.1007/s00484-012-0532-z, 2012a.

Sofiev, M., Siljamo, P., Ranta, H., Linkosalo, T., Jaeger, S., Jaeger, C., Rassmussen, A., Severova, E., Oksanen, A., Karppinen, A., and Kukkonen, J.: From Russia to Iceland: an evaluation of a large-scale pollen and chemical air pollution episode during April and May, 2006, in: Aerobiological Monographs, Towards a Comprehensive Vision, edited by: Clot, B., Comtois, P., and Escamilla-Garcia, B., 95-113, 2012b.

Stach, A., Smith, M., Skjøth, C. A., and Brandt, J.: Examining Ambrosia pollen episodes at Poznań (Poland) using back-trajectory analysis, Int. J. Biometeorol., 51, 275-286, doi:10.1007/s00484006-0068-1, 2007.

Tampieri, F., Mandrioli, P., and Puppi, G. L.: Medium range transport of airborne pollen, Agric. Meteorol., 18, 9-20, 1977.

Venkatram, A.: Estimating the convective velocity scale for diffusion applications, Bound. Lay.-Meteorol., 15, 447-452, 1978.

Veriankaite, L., Siljamo, P., Sofiev, M., Sauliene, I., and Kukkonen, J.: Modelling analysis of source regions of long-range transported birch pollen that influences allergenic seasons in Lithuania, Aerobiologia (Bologna), 26, 47-62, doi:10.1007/s10453009-9142-6, 2010.
Viander, M. and Koivikko, A.: The seasonal symptoms of hyposensitized and untreated hay fever patients in relation to birch pollen counts: correlation with nasal sensitivity, prick tests and RAST, Clin. Allergy, 8, 387-396, 1978.

Vira, J. and Sofiev, M.: On variational data assimilation for estimating the model initial conditions and emission fluxes for shortterm forecasting of SOx concentrations, Atmos. Environ., 46, 318-328, doi:10.1016/j.atmosenv.2011.09.066, 2012.

Vogel, H., Pauling, A., and Vogel, B.: Numerical simulation of birch pollen dispersion with an operational weather forecast system, Int. J. Biometeorol., 52, 805-814, doi:10.1007/s00484-0080174-3, 2008.

Walcek, C. J. and Aleksic, N. M.: A simple but accurate mass conservative, peak-preserving, mixing ratio bounded advection algorithm with FORTRAN code, Atmos. Environ., 32, 3863-3880, doi:10.1016/S1352-2310(98)00099-5, 1998.

WHO: Phenology and human health: allergic disorders, Copenhagen, 2003.

Williamson, D. L. and Rasch, P.: Two-Dimensional SemiLagrangian Transport with Shape-Preserving Interpolation, Am Meteorol. Soc., 117, 102-129, 1989.

Wright, J. W.: Pollen dispersion of some forest trees., Northeastern Forest Experiment Station, Forest Service, U.S. Dept. of Agriculture, Station paper 46, February 1952, 42 pp., 1952.

Wright, J. W.: Pollen dispersion studies: Some practical applications, J. Forestry, 114-118, 1953.

Yli-Panula, E., Fekedulegn, D. B., Green, B. J., and Ranta, H.: Analysis of Airborne Betula Pollen in Finland?; a 31-Year Perspective, Int. J. Environ. Res. Public Health, 6, 1706-1723, doi:10.3390/ijerph6061706, 2009.

Zhang, L., Gong, S., Padro, J., and Barrie, L.: A size-segregated particle dry deposition scheme for an atmospheric aerosol module, Atmos. Environ., 35, 549-560, 2001.

Zink, K., Pauling, A., Rotach, M. W., Vogel, H., Kaufmann, P., and Clot, B.: EMPOL 1.0: a new parameterization of pollen emission in numerical weather prediction models, Geosci. Model Dev., 6, 1961-1975, doi:10.5194/gmd-6-1961-2013, 2013. 